\title{
Influence of Plant Population and NPSB Blended Fertilizer Rates on Yield Parameters and Yield of Maize (Zea mays L.) in Bako, Ethiopia
}

\author{
Fufa Anbessa Feyisa, Thomas Abraham" and Habtamu Ashagre \\ Department of Plant Sciences, College of Agriculture \& Veterinary Sciences, Ambo University, Ethiopia, P.O. Box -19 \\ Communication author: drthomasabraham7@gmail.com (ORCID ID: 0000-0002-3241-5038)
}

Paper No. 803

Received: 06-07-2019

Revised: 03-10-2019

Accepted: 28-11-2019

\begin{abstract}
Maize (Zea mays L.) is ranked number one in total production among food grains and is inevitable in achieving food security in Ethiopia. In spite of good agro-climatic conditions and soils, maize productivity is constrained by a number of problems; optimum plant population and nutrient management are the most critical among many others. Hence, this field experiment was carried out in split plot design distributing three levels of plant population 53,333 plants/ha, 66,666 plants/ha, and 76923 plants/ha in the main plots and five levels of NPSB fertilizer rates 0,100,150,200 and $250 \mathrm{~kg} / \mathrm{ha}$ in sub-plots comparing with NP recommended rates in the research area. The two main effects, the plant population and NPSB rate did not change cob length, number of row $\mathrm{cob}^{-1}$ and harvest index. The analysis of variance showed the interaction of plant population and NPSB rates influenced number of kernels $\mathrm{cob}^{-1}$, thousand kernel weight, number of cobs per plot and above ground biomass. Highest number of cob plot $^{-1}$ was recorded from the plot with 66,666 plants ha ${ }^{-1}$ and highest biological yield $28299 \mathrm{~kg} / \mathrm{ha}$ was harvested from the plot with standard check. The highest grain yield was obtained from $150 \mathrm{~kg} / \mathrm{ha}$ with the plant population of 66666 plants/ha $(60 \mathrm{~cm} \times 25 \mathrm{~cm})$. From the research it was concluded that the yield of maize was significantly affected by fertilizer rates and plant population, the combination of 66,666 plant/ha and 150 $\mathrm{kg} / \mathrm{ha}$ of NPSB fertilizer rate was found to be superior and economically viable for maze production in the study area and similar agro ecologies.

Highlights

(0 Highest plant population treatment of 76923 plants ha ${ }^{-1}(65 \mathrm{~cm} \times 20 \mathrm{~cm})$ has produced the highest grain yield.

- Application of NPSB blended fertilizer significantly improved the grain yield and yield components of maize, highest grain yield of $9717 \mathrm{~kg} \mathrm{ha}^{-1}$ was recorded from the application of $150 \mathrm{~kg} / \mathrm{ha}$ of NPSB fertilizer with $\mathrm{N} 92 \mathrm{~kg} \mathrm{ha}^{-1}$ in split application.

(0) Optimum plant population of 66,666 plants ha-1 $(60 \mathrm{~cm} \times 25 \mathrm{~cm}$ spacing) with optimum amount of $150 \mathrm{~kg}$ NPSB fertilizer substantially enhanced yield and yield components of maize at Bako.
\end{abstract}

Keywords: Maize, Yield, Plant population, NPSB fertilizer rate

Maize (Zea mays L.) is one of the most important crop and ranks top spot in terms of total production among food grains and plays a critical role in achieving food security in Ethiopia. In spite of good agro-climatic conditions and soils, maize productivity is constrained by a number of problems; optimum plant population and nutrient management are the most critical among many others.

Maize is the main staple food for millions of people in developing countries especially in Sub-Saharan Africa. It is an important source of protein and energy for mankind as well as animals and a source of raw material for the industry. It is a $\mathrm{C} 4$ plant with 
a great photosynthetic efficiency and has capacity to produce more photsynthates with less water loss as compared to C3 plants.

The estimated average yields of maize for smallholder farmers in Ethiopia are about 3.2 tons $\mathrm{ha}^{-1}$, which is much lower than the yield recorded under demonstration plots which was 5 to 6 tons ha ${ }^{1}$ CSA, (2017). Hence, the potential maize productivity in the country has not yet been full exploited. Sitespecific optimum fertilizer rates for maize in the country was not recommended in all regions and the awareness among farmers are less for optimum inorganic fertilizer due to knowledge gap. Lack of optimum plant population per hectare is also another factor for yield reduction in maize. Over population, under population and inadequate seed rate as per variety are important problem, which limits productivity potential in maize.

\section{MATERIALS AND METHODS}

Field experiment was conducted in 2018-19 main cropping season under rain fed conditions at Bako, Oromia National Regional State. Bako Agricultural Research Center is geographically located at $9^{\circ} 06^{\prime}$ $\mathrm{N}$ and $37^{\circ} 09^{\prime} \mathrm{E}$ latitude and longitude respectively. The study area is about $260 \mathrm{~km}$ away from Addis Ababa, the capital city. Bako is in mid-altitudes about $1650 \mathrm{~m}$ a s$^{-1}$.

High yielding maize hybrid variety $\mathrm{BH}-546$ adapted to the agro-ecology of the area, was used for the experiment. NPSB blended fertilizer wich contains $18.9 \%$ Nitrogen, $37.75 \% \mathrm{P}_{2} \mathrm{O}_{5^{\prime}} 6.95 \%$ Sulfur and $0.1 \%$ Boron was used in the study.

\section{RESULTS AND DISCUSSION}

\section{Cob length}

There was no statistically significant $(\mathrm{P}<0.05)$ difference in cob length in main and interaction effects among treatments of plant population and NPSB fertilizer levels (Table 1). Magnitude of cob length changed from $19.4 \mathrm{~cm}$ to $19 \mathrm{~cm}$ when the plant population increased from 53,333 to 66,666 and 76923 plants ha ${ }^{-1}$. Only numerical change (18.6 to $19.6 \mathrm{~cm}$ ) was observed among treatments as the amount of fertilizer level increased from control. The result was in agreement with Raouf and Ali (2016) who reported that the amount fertilizer increased the length of the cob also increased than the control.

\section{Number of rows per cob}

The statistical analysis showed that $(\mathrm{P}<0.05)$ there was no significant difference among treatments due to different plant populations except that of magnitude. When the plant population increased from 53,333 plant/ha to 66,666 plants/ha and 76,923 plants/ha, the rows per cob reduced from 15.8 to 14.9 but the change was not significantly different (Table 1). Application of different levels of NPSB fertilizers did not change the number of rows per cob. Interaction of the plant population and NPSB fertilizer rate also did not change the number of rows per cob. This result was similar with result reported by Raouf and Ali (2016) that the application of additional fertilizer did not significantly change number of rows per cob. This may be due to the fact that rows per cob in maize are formed at the early growth stage of maize when there is not much competition among plants for nutrients for growth and development.

Table 1: Main effect of fertilizer rate and plant population on maize cob length, number of rows cob${ }^{1}$ and harvest index

\begin{tabular}{llll}
\hline Treatment & $\begin{array}{l}\text { Cob length } \\
(\mathbf{c m})\end{array}$ & NROW & $\begin{array}{l}\text { Harvest } \\
\text { Index } \mathbf{( \% )}\end{array}$ \\
\hline NPSB rates & & & \\
\hline 0 & 18.6 & 14.7 & 41.7 \\
$92 / 69 \mathrm{NP}$ & 18.6 & 15.5 & 37.92 \\
100 & 19.44 & 15.04 & 39.9 \\
150 & 19.6 & 15.09 & 37.7 \\
200 & 18.9 & 14.82 & 37.6 \\
250 & 19.4 & 15.16 & 38.64 \\
\hline CV & 6.6 & 4.5 & 8.3 \\
LSD & 1.2 & 0.7 & 3.1 \\
F-Prob & $\mathrm{ns}$ & $\mathrm{ns}$ & $\mathrm{ns}$ \\
\hline Plant population & & & \\
\hline $53,333\left(25 \mathrm{~cm}^{*} 75 \mathrm{~cm}\right)$ & 19.4 & 15.82 & 39.37 \\
$66,666\left(60 \mathrm{~cm}^{*} 25\right)$ & 18.9 & 14.96 & 39.27 \\
$76,923\left(65 \mathrm{~cm}^{*} 20 \mathrm{~cm}\right)$ & 19 & 14.91 & 38.08 \\
\hline CV & 6.6 & 4.5 & 8.3 \\
LSD & 0.7 & 0.46 & 2.19 \\
F-Prob & $\mathrm{ns}$ & $\mathrm{ns}$ & $\mathrm{ns}$ \\
\hline
\end{tabular}

NROW $=$ Number of rows $c o b^{-1}$

\section{Harvest index (HI\%)}

Harvest index of the crop is a reflection of division of photosynthates between the seeds and the 
vegetative plant part and improvement in harvest index emphasizes the importance of carbon allocation in grain production.

There was no significant difference among treatments of NPSB fertilizer levels and plant population on harvest index at $\mathrm{P}<(0.05)$ level of significance. However, only numerical change was observed from both level of factors plant population and fertilizer levels (Table 1). Adamu et al. (2015) reported similar results in harvest index in maize research.

\section{Number of cobs per plot}

Regarding the number of cobs per plot, there was significant difference among treatments of plant population and level of NPSB rates. Interaction of plant population and fertilizer rates also significantly influenced the number of cobs plot $^{-1}$, highest cob number 118, followed by 115 and 113 cobs per plot were recorded from the interaction of 66,666 plants/ha with $250 \mathrm{~kg} / \mathrm{ha}$ NPSB fertilizer rate, 66,666 plants/ha with $150 \mathrm{~kg} / \mathrm{ha}$ NPSB fertilizer rate, and 66666 plant/ha with $100 \mathrm{~kg} / \mathrm{ha}$ NPSB fertilizer rate, respectively. Lowest cob number 81 cobs per plot were recorded from the interaction of 53,333 p/ha and control (Table 2).

Table 2: Interaction effects of plant population and fertilizer rate on number of cob plant ${ }^{-1}$

\begin{tabular}{|c|c|c|c|c|}
\hline \multirow{2}{*}{$\begin{array}{l}\text { Fertilizer Rates } \\
(\mathrm{NPSB}+\mathrm{N}) \mathrm{kg} \\
\mathrm{ha}^{-1}\end{array}$} & \multicolumn{4}{|c|}{$\begin{array}{l}\text { Plant population with intera and inter } \\
\text { spacing }\end{array}$} \\
\hline & $\begin{array}{l}53,333 \\
\text { plants ha }\end{array}$ & $\begin{array}{l}66,666 \\
\text { plants ha-1 }\end{array}$ & $\begin{array}{l}76,923 \\
\text { plants ha-1 }\end{array}$ & Mean \\
\hline 0 & 81de & 106.0abcd & 85.0cde & 88.1 \\
\hline $92 / 69 \mathrm{NP}$ & $73.33 \mathrm{e}$ & 99.3abcde & $110.0 \mathrm{abc}$ & 96.8 \\
\hline 100 & $82.67 \mathrm{de}$ & $113.0 \mathrm{ab}$ & 102.7abcd & 99.4 \\
\hline 150 & 81.33de & 115.3a & 107.3abcd & 101.3 \\
\hline 200 & 87.0 bcde & 106.0abcd & 104.0abcd & 99.0 \\
\hline 250 & $87.67 \mathrm{bcde}$ & $118.0 \mathrm{a}$ & 106.3abcd & 104.0 \\
\hline Mean & 82.2 & 109.6 & 102.6 & 98.1 \\
\hline $\mathrm{CV}(\%)$ & & 8.2 & & \\
\hline LSD (0.05) & & 13.51 & & \\
\hline F-prob & & * & & \\
\hline
\end{tabular}

This result agreed with the results reported by Besufikad and Tesfaye (2018) who reported as interaction of optimum plant population and fertilizer rate improved the number of cobs harvested per plot. Onasanya et al. (2009) reported that optimum plant population may facilitate to the plants to use the resources and the optimum fertilizer rate helps the plant to be nourished through its growth seasons.

\section{Number of kernels per cob}

Number of kernels per cob is the very prominent factor, which influences yield in the maize. There was no significant difference among treatments of plant population and levels of NPSB fertilizer rates in maize (Table 3).

Table 3: Interaction effects of plant population and fertilizer rates on number of kernels $\mathrm{cob}^{-1}$

\begin{tabular}{|c|c|c|c|c|}
\hline \multirow{2}{*}{$\begin{array}{l}\text { Fertilizer Rates } \\
(\mathrm{NPSB}+\mathrm{N}) \mathrm{kg} \\
\text { ha }^{-1}\end{array}$} & \multicolumn{4}{|c|}{$\begin{array}{l}\text { Plant population with intera and inter } \\
\text { spacing }\end{array}$} \\
\hline & $\begin{array}{l}53,333 \\
(75 \mathrm{~cm} \times \\
25 \mathrm{~cm})\end{array}$ & $\begin{array}{l}66,666 \\
(60 \mathrm{~cm} \times \\
25 \mathrm{~cm}\end{array}$ & $\begin{array}{l}76,923 \\
(65 \mathrm{~cm} \times \\
20 \mathrm{~cm})\end{array}$ & Mean \\
\hline 0 & $642.8 a$ & $620.2 \mathrm{ab}$ & $478.2 b$ & 580.4 \\
\hline 92/69 NP & $637.8 \mathrm{ab}$ & $656.5 a$ & $629.9 \mathrm{ab}$ & 641.4 \\
\hline $100+73.1$ & 611.7ab & 593.1ab & $595.5 \mathrm{ab}$ & 600.1 \\
\hline $150+63.65$ & $634.2 \mathrm{ab}$ & $574.3 \mathrm{ab}$ & $666.4 \mathrm{a}$ & 625 \\
\hline $200+54.2$ & $614.9 \mathrm{ab}$ & $629.3 \mathrm{ab}$ & $595.6 \mathrm{ab}$ & 615.3 \\
\hline $250+44.7$ & $622.8 \mathrm{ab}$ & $614.7 \mathrm{ab}$ & $653.7 \mathrm{a}$ & 630.4 \\
\hline Mean & 627.4 & 614.7 & 603.2 & \\
\hline CV (\%) & & 8.1 & & \\
\hline LSD (0.05) & & 82.48 & & \\
\hline F-prob & & * & & \\
\hline
\end{tabular}

However, there was significant difference in interaction effects of plant population and level of NPSB fertilizer rates. Highest kernel number of 666 kernels/cob was registered from the treatment with 76,923 plants per hectare and $150 \mathrm{~kg} / \mathrm{ha}$ NPSB fertilizer rate followed by 656.5 kernels/cob from the treatment with $92 \mathrm{~N}$ and $69 \mathrm{P}_{2} \mathrm{O}_{5} \mathrm{~kg} / \mathrm{ha}$. Lowest number of kernels per cob was recorded from the treatment of 76,923 plant/ha and zero fertilizer application. Lowest number of grain per cob was obtained from the highly dense plant population of $76,923 \mathrm{plant} / \mathrm{h}$ and zero fertilizer application. Reason behind this results may be the competition among plants for resources which lead to the smallest cobs and small cob can produce only limited grains. The plants that were provided with sufficient NPSB fertilizer has higher capability to utilize nutrients and facilitate to use other nutrients from the soil and produce bigger cobs that produces more number of grains per cob. Interaction of optimum NPSB fertilizer rate and plant population can increase 
number of kernels per cob due to the fact that rows formed at early growth stages are developed to full kernels. Anbessa et al. (2018) reported similar results from his maize research in Assosa.

\section{Grain yield}

Plant population, fertilizer rates and their interactions significantly affected grain yield. Highest grain yield of $9,393 \mathrm{~kg} / \mathrm{ha}$ was recorded from the plant population of 76,923 plant/ha followed by 8,830 $\mathrm{kg} /$ ha grain yield from a plant population of 66,666 plant/ha. The lowest grain yield of $8316 \mathrm{~kg} / \mathrm{ha}$ was recorded from the farmer's practice, which is 53,333 plant/ha (Table 4). Increase of plant population over the farmers practice of 53,333 plants/ha to 66,666 plant/ha has increased yield advantage by $7 \%$ and when plant population increased to 76,923 plants/ ha, the yield advantage over the farmers practice was $12 \%$. This may happen due to fact that optimum plant population efficiently utilizes resource in the soil such as water, nutrient, sunlight and spaces and compete with the weed.

Highest grain yield of $9717 \mathrm{~kg} / \mathrm{ha}$ was recorded from application of $150 \mathrm{~kg} / \mathrm{ha}$ of NPSB fertilizer with N $92 \mathrm{~kg} / \mathrm{ha}$ in split application followed by $100 \mathrm{~kg} / \mathrm{ha}$ which has produced a grain yield of $9448 \mathrm{~kg} / \mathrm{ha}$. The third highest grain yield of $9,385 \mathrm{~kg} /$ ha was recorded from the treatment with $250 \mathrm{~kg} / \mathrm{ha}$. The lowest grain yield of $6144 \mathrm{~kg} / \mathrm{ha}$ was recorded from the control, which was without any fertilizer application (Table 4). These two treatments $100 \mathrm{~kg} / \mathrm{ha}$ and $150 \mathrm{~kg} / \mathrm{ha}$ gave higher yield advantage of $2 \%$ and $5 \%$ than the standard check. Similar grain yield result was also reported by Onasanya et al. (2009) in maize research. As rate of fertilizer increased up to certain level, the yield of maize increased proportionately. This might be due to fact that optimum fertilizer application nourishes and supplies nutrients required for good productivity.

Interaction effect of fertilizer and plant population also affected grain yield of maize. The highest grain yield of 10,908 kg/ha was recorded from the interaction of 76,923 plant/ha and $100 \mathrm{~kg} / \mathrm{ha}$ NPSB fertilizer rate, followed by the interaction of 76,923 plant/ha and recommended NP (92/69) that recorded $10303 \mathrm{~kg} / \mathrm{ha}$ grain yield. Plot with 66,666 plant/ha and $150 \mathrm{~kg} / \mathrm{ha}$ NPSB fertilizer rate produced 10014 $\mathrm{kg} /$ ha grain yield, which is a substantial advantage over the control. Lowest grain yield of $4701 \mathrm{~kg} / \mathrm{ha}$ was recorded from the plot with farmers practice i.e., plant population of 53,333 plants/ha and zero fertilizer (Table 4).

Table 4: Effect of plant population and fertilizer rate on grain yield

\begin{tabular}{|c|c|c|c|c|}
\hline \multirow{2}{*}{$\begin{array}{l}\text { Fertilizer Rates } \\
(\mathrm{NPSB}+\mathrm{N}) \mathrm{kg} \\
\text { ha }^{-1}\end{array}$} & \multicolumn{4}{|c|}{$\begin{array}{l}\text { Plant population with intera and inter } \\
\text { spacing }\end{array}$} \\
\hline & $\begin{array}{l}53,333 \\
(75 \mathrm{~cm} \times \\
25 \mathrm{~cm}) \\
\end{array}$ & $\begin{array}{l}66,666 \\
(60 \mathrm{~cm} \times \\
25 \mathrm{~cm}) \\
\end{array}$ & $\begin{array}{l}76,923 \\
(65 \mathrm{~cm} \times \\
20 \mathrm{~cm})\end{array}$ & Mean \\
\hline 0 & $4701 \mathrm{f}$ & 7490de & $6241 \mathrm{ef}$ & $6144 b$ \\
\hline 92/69 NP & 9409abcd & 8115 bcde & $10303 \mathbf{a b}$ & $9276 a$ \\
\hline $100+73.1$ & 7981cde & 9454abcd & $10908 a$ & $9448 a$ \\
\hline $150+63.65$ & 9167abcd & $10014 a b c$ & $9944 a b c$ & $9717 a$ \\
\hline $200+54.2$ & 9167abcd & 8866abcd & 9303abcd & $9112 a$ \\
\hline $250+44.7$ & 9458abcd & 9037abcd & 9660abcd & $9385 a$ \\
\hline Mean & $8318 b$ & $8830 a b$ & $9393 a$ & 8848 \\
\hline CV (\%) & & 7.9 & & \\
\hline LSD (0.05) & & 1158.4 & & \\
\hline F-prob & & $<0.001$ & & \\
\hline
\end{tabular}

Means with similar letter showed non-significant difference.

Showed there is significant difference among treatments.

This research portrayed that maize grain yield was influenced by the plant density and amount of fertilizer applied per unit area. Maize belongs to grass species and is sensitive to plant spacing and it is also a heavy feeder crop and sensitive to fertilizer applied per unit area. Increased plant population increases grain yield up to certain level and can fight to overcome the competition of weeds for available resources. As plant population density increased from 53,333 plat/h to 66,666 plant/ha with application of similar NPSB fertilizer rate, yield increased on the dense population by $10 \%$ with similar fertilizer rate and $9 \%$ on the plant population of 76923 plant/ha with similar fertilizer rate. In this study the plots treated with the fertilizer of $150 \mathrm{~kg} / \mathrm{ha}$ and 66,666 plant/ha produced enhanced grain yield of 10,014 kg/ha (Table 4). The balanced nitrogen, phosphorus and sulfur levels might have helped in efficient absorption and utilization of other required plant nutrients which ultimately increased the grain yield. Progressive increase of plant population and amount of fertilizer increased the grain yield up to certain level. Similar results were also reported by Tolera et al. (2009) from his maize research in Ethiopia. Increase in grain yield 
up to certain level of NPSB is directly related to the vegetative and reproductive growth phases of the crop and attributes to complex phenomenon of NPSB utilization in plant metabolism. Similar research findings were also reported by Vijaya et al. (2018) from the maize research conducted in India.

\section{CONCLUSION}

To conclude, plant population practice of farmers which is 53,333 plants/ha in $25 \mathrm{~cm} \times 75 \mathrm{~cm}$ spacing has given lower yield than the newly designed plant population 66,666 plants/ha and 76,923 plants/ha with the amendment of plant spacing (inter-row and intera-row spacing) which are $60 \mathrm{~cm} \times 25 \mathrm{~cm}$ and $65 \mathrm{~cm} \times 20 \mathrm{~cm}$ respectively. Moreover, better space, light, water, nutrients and other natural resources are effectively used by plants along with reduced weed infestation to enhance productivity. The highest plant population treatment of 76923 plants $/$ ha $(65 \mathrm{~cm} \times 20 \mathrm{~cm})$ has produced the highest yield in this research.

Optimum NPSB fertilizer rate with the optimum plant population was $150 \mathrm{~kg}$ NPSB. It was also concluded that optimum fertilizer rate improved the yield and yield components of maize at Bako. Recommendation for optimum plant population in this research is based on the economic profitability considering fertilizer cost and other resources. Therefore, it is recommended to the farmers of the area to use the optimum plant population of 66,666 plants/ha $(60 \mathrm{~cm} \times 25 \mathrm{~cm}$ spacing $)$ with optimum amount of $150 \mathrm{~kg}$ NPSB fertilizer rate. Further research comparing various other suitable plant populations and NPSB fertilizer levels may be carried out in future to validate the findings in similar other agro-ecologies.

\section{REFERENCES}

Adamu, U.K., Jerome, P.M. and Msaky, J.J. 2015. Growth Response of Maize (Zea mays L.) to Different Rates of Nitrogen, Phosphorus and Farm Yard Manure in Morogoro Urban District, Tanzania, American Journal of Experimental Agriculture, 9(2): 1-8.

Anbessa, B., Tamene, D., Legesse, T. and Dereje, G. 2018. Effect of Inorganic and Organic Fertilizer Application on Growth and Yield of Maize and Soil Fertility in Assosa Zone, Soil Fertility and Plant Nutrient Management, Ethiopian Institute of Agricultural Research (EIAR), 2018.

Besufikad, E. and Tesfaye, D. 2018. Response of Maize Yield and Yield Related Components to Different Levels of Nitrogen and Phosphorus Fertilizers, Acta Scientific Agriculture, 3(1).

Onasanya, R., Aiyelari, A., Onasanya, S. Oikeh, F. and Oyelakin, O. 2009. Growth and Yield Response of Maize (Zea mays L.) to different rates of nitrogen and phosphorus fertilizers in Southern Nigeria, World Journal of Agricultural Sciences, 5(4): 400-407.

Raouf, S. and Ali, N. 2016. Effects of time and rate of nitrogen application on phenology and some agronomical traits of maize (Zea mays L.), BIOLOGIJA. 62(1): 35-45.

Tolera, A., Daba, F. and Friesen, D.K. 2009. Effects of Crop Rotation and N-P Fertilizer Rate on Grain Yield and Related Characteristics of Maize and Soil Fertility at Bako, Western Oromia, Ethiopia. East African Journal of Sciences, 3(1): 70-79.

Vijaya, B.R.U., Prabhakara, R.G., Srinivasa, R.M. and Kavitha, P. 2018. Effect of Different Nitrogen and Phosphorus Levels on Growth and Yield of Maize during Kharif Season, India. International Journal of Current Microbiology and Applied Sciences, 7(1): 3548-3555. 
